\title{
SCIENTIFIC REPORTS

\section{Decomposition characteristics of indigenous organic fertilisers and introduced quick compost and their short-term nitrogen availability in the semi-arid Ethiopian Rift Valley}

\begin{abstract}
Shiro Mukai $i^{1 *} \&$ Wataru Oyanagi ${ }^{2}$
Case studies on the assessment of local organic fertilisers (OFs) in their quality (decomposition characteristics and nutrient availability for crops) are few in sub-Saharan Africa (SSA). This study assessed the quality of local OFs from the Ethiopian Rift Valley. The decomposition characteristics were assessed by acid detergent fibre analysis methods, while the short-term nitrogen availability was assessed by a combination of laboratory incubations and inorganic nitrogen and acid detergent soluble nitrogen determinations. A commercial hand-held reflectometer (ROFlex) was used for determining nitrogen components. The mean acid detergent soluble organic matter contents exceeded $250 \mathrm{mg} \mathrm{g}^{-1}$, indicating the OF feedstock contained much of the readily decomposable organic matter. Some of the indigenous compost (kosi) samples showed net nitrogen immobilisation during the initial period of incubation, followed by net nitrogen mineralisation in one month of incubation with $4 \%$ of the nitrogen mineralisation rate. Kosi should be applied to a field one month before seeding. Short-term nitrogen availability from kosi was too low to substitute for inorganic fertilisers. The combination of the simple analysis methods shown in this study is a quick, cost-saving, and accurate quality assessment approach for OFs, which can be useful in the field and at experimental stations in SSA.
\end{abstract}

In broader parts of Eastern and Southern Africa, cattle are the most important livestock and are kept for ploughing, milk, and manure uses ${ }^{1}$. These areas also suffer soil fertility decline due to high agricultural and grazing pressures $^{2}$. To overcome low soil fertility problems, most of the farmers are constrained by a shortage of cash to use inorganic fertilisers (IFs); however, farm-level fertiliser prices in sub-Saharan Africa (SSA) are among the highest in the world ${ }^{3}$. Many medium-term (over 5 years and more) soil fertility management experiments conducted in SSA invariably showed that the best results in terms of medium-term sustained yield response were from those treatments that combined inorganic and organic inputs ${ }^{4}$. Given these contexts, the combined use of organic fertilisers (OFs) and IFs has been advocated in SSA since the $1990 \mathrm{~s}^{5}$.

The major limitation in the effectiveness of OFs in SSA involves their quality and quantity; first, farmers cite quantity as a problem, that OFs are usually not enough, and second, the quality of OFs concerning nutrient release and crop uptake is poor ${ }^{6}$. Commonly available organic resources among smallholder farmers in SSA have divergent qualities ${ }^{7}$, which decompose and release various qualities of nutrients in soils at different times ${ }^{8}$, reflecting differences in nutrient availability and overall crop yields from each resource ${ }^{9}$. Besides these two parameters, i.e., decomposition characteristics and nutrient availability, maturity and stability are other important parameters for quality assessment of $\mathrm{OFs}^{10}$. A well-accepted definition of compost stability is the rate or degree of organic matter (OM) decomposition. Compost maturity generally refers to the degree of decomposition of phytotoxic organic substances produced during the active composting phase and to the absence of pathogens and visible weed seeds ${ }^{11}$.

Case studies on the quality assessment of local OFs in SSA include: (i) analyses of different decomposition characteristics and nutrient availability to establish a decision-support system for farmers ${ }^{8,12}$; (ii) analyses of

\footnotetext{
${ }^{1}$ 1-19-7 Omorinishi, Ota-ku, Tokyo, 143-0015, Japan. ${ }^{2}$ Niigata Livestock Research Center, Niigata, 955-0143, Japan.

*email: shiro_mukai@yahoo.co.jp
} 


\begin{tabular}{|c|c|c|c|c|c|c|c|c|c|c|c|c|c|}
\hline \multirow[b]{2}{*}{ Manure and compost } & \multirow[b]{2}{*}{$n$} & \multicolumn{3}{|l|}{$\mathbf{N}(\%)$} & \multicolumn{3}{|l|}{$\mathbf{P}(\%)$} & \multicolumn{3}{|l|}{$\mathrm{K}(\%)$} & \multicolumn{3}{|l|}{ C:N } \\
\hline & & mean & $\min$. & $\max$ & mean & $\min$. & $\max$ & mean & $\min$. & $\max$ & mean & $\min$. & $\max$ \\
\hline $\begin{array}{l}\text { Cattle manure } \\
\text { (compost) })^{7,9,13,14,16,29,55-57}\end{array}$ & 506 & 1.2 & 1.1 & 1.7 & 0.3 & 0.2 & 0.6 & 2.1 & 0.8 & 2.4 & 23 & 12 & 29 \\
\hline Sheep and goat manures 7,56 & 75 & 1.5 & 1.5 & 1.5 & 0.2 & 0.2 & 0.4 & 3.0 & 1.4 & 3.3 & 22 & 22 & 22 \\
\hline Chicken manure $^{7,55,56}$ & 87 & 3.2 & 2.4 & 3.8 & 0.4 & 0.4 & 1.6 & 2.2 & 0.9 & 2.4 & 10 & 9 & 17 \\
\hline Fast compost ${ }^{7,29}$ & 83 & 1.4 & 0.7 & 2.0 & 0.3 & 0.2 & 0.4 & 1.8 & 1.4 & 1.8 & 13 & 10 & 18 \\
\hline
\end{tabular}

Table 1. Chemical contents of manure and compost samples collected from kraals and animal sheds in local farmers' backyards in Eastern and Southern Africa.

how farmers' management practices affect chemical composition of manure ${ }^{13-15}$; (iii) analysis of the relationship between farmers' simple methods for manure/compost quality assessment and those chemical compositions ${ }^{16}$; and (iv) analyses of how different production and storage methods of cattle manure affected the manure organic $\mathrm{N}$ composition and release in soil ${ }^{17}$. Of these previous studies, (i) discussed decomposition characteristics of OFs and (iv) discussed $\mathrm{N}$ availability from OFs for crops.

A challenge is to determine how researchers can apply the enhanced predictive understanding of the two quality parameters of OFs, decomposition characteristics and nutrient availability, to assist farmers in managing their organic resources ${ }^{18}$. To address this, first, a minimum set of organic resource quality parameters (macronutrients, total carbon (C), lignin, soluble C, soluble polyphenolics, $\alpha$-cellulose, and ash) was recommended ${ }^{12}$, and the resource quality of a variety of crop residues, agroforestry trees and shrubs, and leguminous cover crops were compiled into an Organic Resource Database ${ }^{19}$ in Eastern and Southern Africa.

Second, a decision-support system, which makes practical recommendations for appropriate use of organic materials, based on their total nitrogen $(\mathrm{N})$, lignin, and polyphenol contents, was developed ${ }^{19}$. Gachengo et al. $\left(\right.$ ref. $\left.^{8}\right)$ assessed the nutrient supply characteristics of 32 OF and organic materials (a standard sample set) commonly used for soil fertility management in Kenya by a proximate analysis that used the resource quality parameters of total $\mathrm{N}$, lignin, and polyphenol contents and categorised them into the four quality categories (Classes I-IV). Simultaneously, this standard sample set was analysed by 28 -day aerobic incubations ${ }^{20}$, in vitro dry matter digestibility ${ }^{21}$, and near-infrared reflectance spectrometry ${ }^{22}$. Regression analyses showed that the incubation analysis and in vitro digestibility were still best explained by the three quality parameters, $\mathrm{N}$, lignin, and soluble polyphenol contents, which had been obtained from the proximate analysis ${ }^{23}$. When considerations of cost and speed are included in the analysis, aerobic incubation is one of the cheapest, but it's also the slowest method. Near-infrared reflectance spectrometry is the fastest method, but also the most expensive ${ }^{23}$.

In the decision-support system, cattle manure was categorised into Class II that was characterised by $>2.5 \% \mathrm{~N}^{8}$. A literature review showed that total $\mathrm{N}$ contents of the cattle manure/compost samples collected from kraals (cattle parking lots) and cattle sheds in local farmers' backyards in Eastern and Southern Africa ranged from $1.1 \%$ to $1.7 \%$ with a mean of $1.2 \%$ (Table 1 ). Fast compost samples reviewed from two papers contained $0.7 \% \mathrm{~N}$ and $2.0 \% \mathrm{~N}$ (Table 1). It can be difficult to strictly identify the type of OFs in the field, particularly manure or compost, in the situation that "farmers reported adding organic materials directly to the manure heap, organic materials of which were rejected fodder, maize stover (used by $87 \%$ of the farmers), banana residues $(71 \%)$, Napier grass (47\%), roadside grass (42\%), Grevillea leaves (34\%), and other materials $(16 \%)^{16 \%}$. Thus, representative cattle manure/compost samples collected from farmers' backyard contained less than $2.5 \% \mathrm{~N}$, rather classified into Classes III or IV (both categories were characterised by $<2.5 \% \mathrm{~N}$ ) in the decision-support system.

Thus, case studies on the quality assessment of local OFs, i.e., their decomposition characteristics and nutrient availability for crops, are few in SSA. The first objective of this study is to assess decomposition characteristics of local OFs and their feedstock and to estimate a short-term $\mathrm{N}$ availability from those OFs, which can substitute for IFs, in the semi-arid northern Ethiopian Rift Valley. The second objective is to show an example of cheap, fast, and yet accurate analysis methods for the quality assessment of local OFs in the field and at agricultural experiment stations near the field.

Decomposition characteristics of the OFs and feedstock were assessed using acid detergent fibre methods. The short-term $\mathrm{N}$ availability from the OFs was estimated by laboratory incubations and inorganic $\mathrm{N}$ and acid detergent soluble nitrogen (ADSN) ${ }^{24}$ determinations.

\section{Materials and Methods}

Study area. Most of the Tebo and Geldia seasonal rivers catchments (the study area) are located in the semiarid northern Ethiopian Rift Valley. The catchment areas are categorised into the two sub-areas in terms of major maize growing areas in Ethiopia (these two categories cover $63 \%$ of the total maize growing area in Ethiopia): mid-altitude dry (1000-1600 m a.s.l.; annual rainfall $800-1000 \mathrm{~mm}$ ) and mid-altitude moist (1600-1800 m a.s.l.; annual rainfall $1000-1250 \mathrm{~mm}$ ) sub-areas. Major crops in the mid-altitude dry sub-area of the catchments are sorghum, tef (Eragrostis tef), and maize, whereas those in the mid-altitude moist sub-area are wheat, tef, and maize.

Most households in the semi-arid northern Ethiopian Rift Valley hold continuously cropped maize fields (locally referred to as aradas), which acquire fertility from the regular input of OFs, such as compost (locally, kosi) or household wastes ${ }^{25}$. Kosi is made from a variety of locally available organic materials, such as various types of animal dung, kitchen ash, crop residues, and feed refusals. These compost materials are piled up in the corners of house-yards for several months to a few years for decomposition ${ }^{25}$. It is mainly a housewife who collects these organic materials through house-yard sweeping and dumps on a kosi pile. In most cases, farmers carry kosi from 


\begin{tabular}{|c|c|c|c|c|c|c|c|c|c|}
\hline Items & $n$ & N (\%) & $\mathbf{P}(\%)$ & K (\%) & TOC (\%) & C:N & $\mathrm{Ca}(\%)$ & $\operatorname{Mg}(\%)$ & $\mathrm{Na}(\%)$ \\
\hline Kosi & 28 & $1.52 * * \pm 0.56$ & $0.35^{*} \pm 0.18$ & $1.33^{n s} \pm 0.59$ & $22.49 * * \pm 12.69$ & $18^{n s} \pm 8$ & $2.98^{n s} \pm 1.11$ & $0.55^{n s} \pm 0.33$ & $0.19^{n s} \pm 0.08$ \\
\hline Fast compost & 10 & $0.89 * * \pm 0.23$ & $0.24 * \pm 0.08$ & $1.19^{n s} \pm 0.71$ & $11.05 * * \pm 4.38$ & $19^{n s} \pm 4$ & $2.36^{n s} \pm 0.92$ & $0.42^{n s} \pm 0.29$ & $0.19^{n s} \pm 0.05$ \\
\hline Maize stover & 6 & $1.08 \pm 0.28$ & $0.11 \pm 0.06$ & $2.73 \pm 0.07$ & $49.88 \pm 1.01$ & $48 \pm 10$ & $0.43 \pm 0.06$ & $0.10 \pm 0.02$ & $0.21 \pm 0.02$ \\
\hline Sorghum stover & 6 & $0.71 \pm 0.17$ & $0.12 \pm 0.02$ & $1.70 \pm 0.13$ & $49.95 \pm 1.65$ & $75 \pm 22$ & $0.94 \pm 0.09$ & $0.61 \pm 0.25$ & $0.05 \pm 0.02$ \\
\hline Tef straw & 6 & $1.10 \pm 0.18$ & $0.15 \pm 0.04$ & $1.69 \pm 0.09$ & $50.27 \pm 0.68$ & $47 \pm 7$ & $1.34 \pm 0.40$ & $0.08 \pm 0.04$ & $0.11 \pm 0.01$ \\
\hline Feed refusals & 6 & $1.47 \pm 0.28$ & $0.19 \pm 0.02$ & $1.93 \pm 0.34$ & $35.45 \pm 6.40$ & $23 \pm 4$ & $3.79 \pm 1.05$ & $0.25 \pm 0.04$ & $0.36 \pm 0.13$ \\
\hline Kitchen ash & 6 & $0.54 \pm 0.16$ & $0.64 \pm 0.15$ & $4.39 \pm 1.67$ & $2.32 \pm 2.14$ & $5 \pm 5$ & $10.90 \pm 5.16$ & $0.71 \pm 0.25$ & $0.36 \pm 0.13$ \\
\hline Cattle dung & 6 & $1.64 \pm 0.12$ & $0.25 \pm 0.02$ & $1.87 \pm 0.60$ & $36.76 \pm 7.90$ & $24 \pm 2$ & $2.83 \pm 0.32$ & $0.26 \pm 0.13$ & $0.28 \pm 0.18$ \\
\hline Sheep/goat dung & 6 & $2.48 \pm 0.41$ & $0.26 \pm 0.05$ & $3.23 \pm 0.62$ & $34.81 \pm 4.26$ & $15 \pm 2$ & $4.06 \pm 0.28$ & $0.40 \pm 0.05$ & $0.47 \pm 0.05$ \\
\hline Donkey dung & 6 & $1.95 \pm 0.36$ & $0.36 \pm 0.05$ & $2.31 \pm 0.74$ & $35.81 \pm 4.10$ & $18 \pm 4$ & $3.81 \pm 1.62$ & $0.39 \pm 0.11$ & $0.32 \pm 0.02$ \\
\hline
\end{tabular}

Table 2. Nutrient contents of organic fertilisers and organic materials from the study area (mean $\pm S D)$. T-tests were conducted between the kosi and fast compost. $* * P<0.01, * P<0.05, n s$ not significant. Dry matter content and chemical contents of $\mathrm{N}$ (the wet Kjeldahl method), $\mathrm{P}$ (the vanadomolybdophosphoric acid method), $\mathrm{K}$, $\mathrm{Ca}, \mathrm{Mg}$, and $\mathrm{Na}$ (the atomic absorption spectroscopy method) ${ }^{58}$, and organic C (Walkley-Black dichromate method $)^{59}$ were analysed at the Soil and Water Analysis Laboratory of Horticoop Ethiopia PLC (Debre Zeit) in 2015. A wet triacid $\left(\mathrm{HNO}_{3} / \mathrm{HClO}_{4} / \mathrm{H}_{2} \mathrm{SO}_{4}\right)$ digestion procedure was used for $\mathrm{P}$ and $\mathrm{K}$. Organic $\mathrm{C}$ contents determined were recalculated into those determined by dry combustion methods using autoanalysers ${ }^{60}$.

kosi piles to a field from May to June before crop seeding and scatter it on the ground. The kosi is incorporated into the soil by subsequent ploughings. Household wastes are substantially a variety of organic materials themselves that also comprise kosi, which is collected through house-yard sweeping and is dumped directly on an arada every few days.

Chemical composition analyses of kosi organic feedstock (Table 2) showed the animal dungs tested had higher nutritional values than secondary organic materials, such as crop residues and feed refusals, with minor exceptions across the chemical composition analysed (Table 2). Although these secondary organic materials were added, the $\mathrm{N}$ content of the kosi was comparable to that of sheep and goat manures in Eastern and Southern Africa (Tables 1 and 2). This can be because, although the primary organic material that constituted the kosi was cattle dung, the kosi also contained chicken, sheep, goat, and donkey dungs, which had higher N contents than cattle dung (Table 2). All cattle, sheep, donkeys, and chicken are parked in the same backyard at night ${ }^{26}$. Probably because of the higher $\mathrm{N}$ content, the mean $\mathrm{C}: \mathrm{N}$ ratio of the kosi, 18 , is lower than that of cattle manure/compost in Eastern and Southern Africa, 23 (Tables 1 and 2); however, either value is higher than a standard of stable compost, $10-15^{27}$. The kosi had slightly higher phosphorus $(\mathrm{P})$ contents than the standard of cattle manure/compost in Eastern and Southern Africa (Tables 1 and 2), probably because of kitchen ash that was dumped on the kosi pile (Table 2).

It has been since the beginning of the 2000s when the district agriculture office began giving fast compost training to farmers ${ }^{28}$. The fast compost is made from the same variety of organic materials as kosi and household wastes. The fast compost had significantly lower $\mathrm{N}(P<0.01)$ and $\mathrm{P}(P<0.05)$ than the kosi (Table 2). Both the total $\mathrm{N}$ content and $\mathrm{C}: \mathrm{N}$ ratio of the fast compost were the same level as those of the fast compost made by the farmers after training in Ethiopia $(\mathrm{N}=0.7, \mathrm{C}: \mathrm{N} \text { ratio }=18)^{29}$. Nutrient contents of the fast compost had another feature of low standard deviations across the chemical composition analysed (Table 2). The farmers attending the fast compost training were instructed on the varieties of organic materials and how to pile them up. The lower standard deviation values indicated that the trainees made the fast compost strictly following the instructions. On the other hand, the nutrient contents of the fast compost in Eastern and Southern Africa had the highest variations among the OFs across the chemical composition analysed (Table 1); e.g., the lowest $\mathrm{N}$ content was $0.7^{29}$, while the highest was $2.0^{7}$. This suggests that the varieties and volumes of organic materials used for making fast compost differ widely from one another.

Sample collection. For assessing decomposition characteristics of OFs and organic materials, $k o s i(n=6)$ and representative organic materials of kosi (maize and sorghum stovers, tef straw, feed refusals, kitchen ash, dried cattle dung, dried goat/sheep dung, and dried donkey dung; $n=3$ for each) were sampled from farmers' backyards in each of the mid-altitude dry and mid-altitude moist sub-areas. Five farmers who had participated in the fast compost training from each sub-area were requested to make compost, from which the fast compost samples were collected; i.e., 12 kosi, 10 fast compost, and 6 samples for each organic material in total. Similarly, for predicting short-term $\mathrm{N}$ availability from OFs and organic materials, $5 \mathrm{kosi}, 5$ fast compost, and 5 household wastes samples were collected from each of the sub-areas; i.e., 10 kosi, 10 fast compost, and 10 household wastes samples in total.

For making the fast compost samples, organic materials collected from the farmers' backyards were piled up in a rectangular wooden frame ( $1 \mathrm{~m}$ in width and length and $1.5 \mathrm{~m}$ in depth). Following the technical guidance of Ministry of Agriculture and Rural Development $\left(\right.$ ref. $\left.^{28}\right)$, each 20-cm-deep layer of the (i) maize and sorghum stalks, (ii) animal dungs, and (iii) tef residue and feed refusals were piled up in turn until it reached the top of the pile. The total depth of each material layer was arranged to be the same between (i), (ii), and (iii). Kitchen ash $\left(0.5 \mathrm{~kg} \mathrm{~m}^{-2}\right)$ was sprinkled over each layer of the (i) and (iii). Some humic soil (1-2 cm deep) was spread on top 


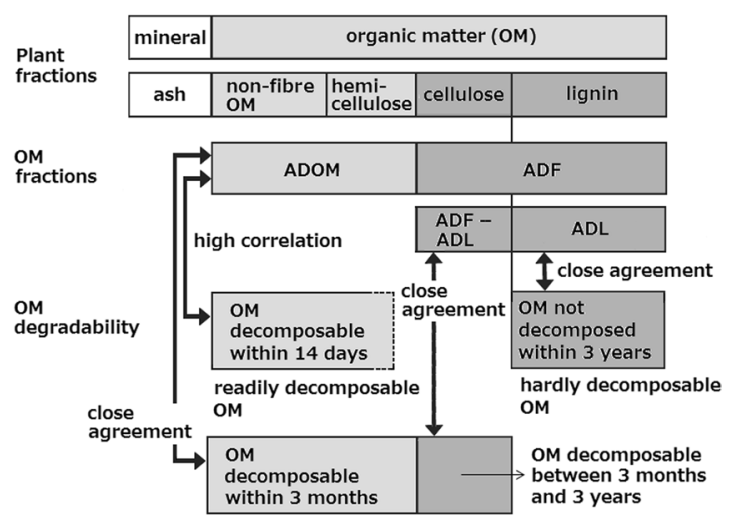

Figure 1. Relationship between plant fractions, organic matter fractions, and organic matter degradability. OM, organic matter; $\mathrm{ADOM}$, acid detergent soluble organic matter; $\mathrm{ADF}$, acid detergent fibre; $\mathrm{ADL}$, acid detergent fibre lignin. Fig. 2 in Oyanagi et al. (ref. ${ }^{32}$ ) and Fig. 2 in Oyanagi et al. $\left(\right.$ ref. $^{35}$ ) were integrated.

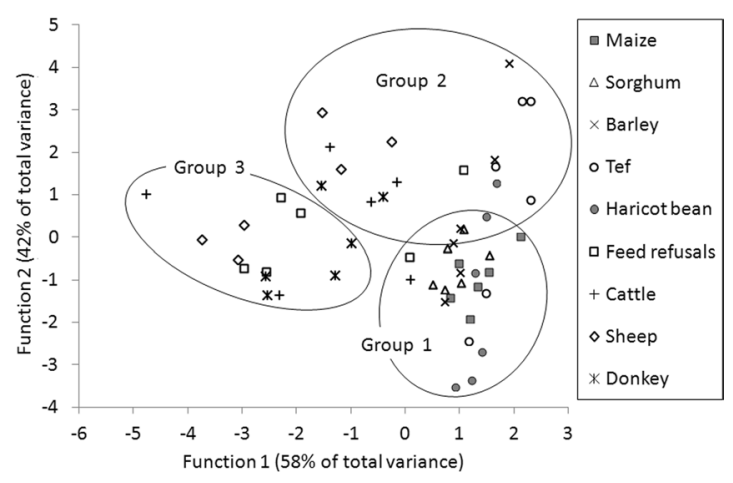

Figure 2. Scatter graph of $1^{\text {st }}$ canonical discriminant score and $2^{\text {nd }}$ canonical discriminant score. Groups 1 to 3 represent the cluster analysis.

of each layer. Water was regularly added to keep the pile moist. Once every 21 days, all the organic materials in the pile were turned over to mix the materials. This process was repeated to make compost ready in 3 months ${ }^{28}$.

Decomposition characteristics. Acid detergent fibre methods have recently been used for a proximate analysis to assess decomposition characteristics of OFs and organic materials ${ }^{30-34}$. By burying OFs and organic materials underground for 3 months $\mathrm{s}^{32}$ and 3 years ${ }^{35}$ using the glass fibre-filter paper bag methods $\mathrm{s}^{33}$ and conducting laboratory incubations $\left(30^{\circ} \mathrm{C}, 14\right.$ days) ${ }^{36}$, Oyanagi et al. ( refs $\left.^{32,35,36}\right)$ confirmed that acid detergent soluble $\mathrm{OM}$ (ADOM; ADOM represents OM other than acid detergent fibre, ADF, that is the sum of non-fibre OM and hemi-cellulose; Fig. 1), ADF, and acid detergent fibre lignin (ADL) can be used for indices to characterize readily decomposable OM (OM decomposable within 14 days), OM not decomposed within 3 months, and hardly decomposable OM (OM not decomposed within 3 years), respectively, for OFs and organic materials in general (Fig. 1; see Decomposition characteristics and Figs. S1, S2 and S3 in Supplementary Information).

In this study, for the kosi, fast compost, and organic materials, OM degradability (Fig. 1), i.e., readily decomposable OM represented by the equation of $0.365 \mathrm{ADOM}-56^{36}$ (see Fig. S2 in Supplementary Information), OM decomposable within 3 months represented by ADOM (i.e., 1000-ADF-crude ash; see Fig. S1), and OM decomposable within 3 years represented by $1000-$ ADL-crude ash (see Fig. S3), were assessed using the acid detergent fibre analysis methods ${ }^{37,38}$.

$\mathrm{N}$ components were determined using a commercial hand-held reflectometer (Merck RQFlex). RQFlex has recently proved to be a rapid on-site estimator of total $\mathrm{N}\left(\mathrm{R}^{2}=0.95\right.$ with the wet Kjeldahl method, $\left.n=98^{34}\right)$, $\mathrm{NH}_{4}^{+}\left(\mathrm{R}^{2}=0.91\right.$ with the stream distillation, $n=107^{39} ; \mathrm{R}^{2}=0.96$ with the stream distillation, $\left.n=36^{40}\right)$, and $\mathrm{NO}_{3}{ }^{-}$ $\left(\mathrm{R}^{2}=0.995\right.$ with the stream distillation, $\left.n=98^{34}\right)$ in manure and organic materials. In this study, total $\mathrm{N}$ determination followed the methods shown in Ando et al. (ref. ${ }^{34}$; see Simple determination method of total N using RQFlex in Supplementary Information).

Based on the values of crude ash (representing mineral), OM, 0.365 ADOM - 56 (similarly, readily decomposable OM representing OM decomposable within 14 days), ADOM (OM decomposable within 3 months), ADF - ADL (OM decomposable between 3 months and 3 years), and 1000 - ADL - ash (OM decomposable within 3 years) obtained, (i) an analysis of variance was conducted to detect differences in these mean values between each pair of the organic materials and (ii) a cluster analysis and canonical discriminant analysis were conducted to get 
cluster numbers and discriminant scores of the each organic material sample, based on which all the samples were grouped. SPSS ver. 20 (IBM) was used for the statistical analyses.

Meanwhile, the kosi sample contained soil, which was mixed in the process of house-yard sweeping, while the fast compost sample contained humic soil. These made determinations of a crude ash content and OM fractions (ADOM, ADF, and ADL) difficult (particularly, ADOM is affected by the crude ash content in the calculation process). However, it is possible to compare the ratios between some indicators of the OM degradability to assess decomposition characteristics of the kosi and fast compost. Kruskal-Wallis tests were applied to detect differences (OM decomposable within 14 days)/(OM decomposable between 3 months and 3 years), (OM decomposable within 14 days)/(OM decomposable within 3 years), (OM decomposable within 3 months)/(OM decomposable between 3 months and 3 years), (OM decomposable within 3 months)/(OM decomposable within 3 years), and (OM decomposable between 3 months and 3 years)/(OM decomposable within 3 years) between each pair of the OFs and organic materials.

Laboratory incubation for predicting short-term $\mathbf{N}$ availability. Laboratory incubations were conducted at room temperature $\left(20-30^{\circ} \mathrm{C}\right)$ and $60 \%$ saturation with water for 42 days. An OF sample containing $30 \mathrm{mgN}$ was mixed with $100 \mathrm{~g}$ of the soil collected from an arada field (Endopetric Hypercalcic Calcisol; clay loam), which was placed in a 100-mL polyethylene bottle. In $3,7,14,21,28,35$, and 42 days of incubation, $100 \mathrm{~mL}$ of $0.5 \mathrm{~mol} \mathrm{~L}^{-1}$ hydrochloric acid was added to $10 \mathrm{~g}$ of the sample and stirred by a mixer for two minutes to make an extract ${ }^{41}$ (see Hydrochloric acid extraction method to determine $\mathrm{NH}_{4}{ }^{+}$and Fig. S4 in Supplementary Information). The extract was diluted, if necessary, and was reacted with Reflectquant ammonium test $(0.2-$ $7.0 \mathrm{mg} \mathrm{L}^{-1} \mathrm{NH}_{4}{ }^{+}$) and Reflectquant nitrate test (5-225 $\mathrm{mg} \mathrm{L}^{-1} \mathrm{NO}_{3}{ }^{-}$) to determine $\mathrm{NH}_{4}{ }^{+}$and $\mathrm{NO}_{3}{ }^{-}$contents with an RQFlex, respectively. Net $\mathrm{N}$ mineralised was calculated by subtracting $\mathrm{NH}_{4}{ }^{+}$and $\mathrm{NO}_{3}{ }^{-}$concentrations of an incubated control (the soil without OF) from $\mathrm{NH}_{4}{ }^{+}$and $\mathrm{NO}_{3}{ }^{-}$concentrations of an incubated sample.

Stability/maturity indices established for composts of various origins, $<0.4 \mathrm{mg} \mathrm{g}^{-1}$ for $\mathrm{NH}_{4}^{+42},>0.3 \mathrm{mg} \mathrm{g}^{-1}$ for $\mathrm{NO}_{3}{ }^{-43}$, and $<1$ for $\mathrm{NH}_{4}{ }^{+}: \mathrm{NO}_{3}^{-}$ratio ${ }^{44}$ were used for assessing stability/maturity of the three OFs.

Inorganic $\mathbf{N}$ and ADSN determinations for predicting short-term $\mathbf{N}$ availability. Acid detergent fibre analysis methods have recently been used for a proximate analysis to predict available $\mathrm{N}$ from OFs ${ }^{24,45,46}$. Based on the results of laboratory incubations $\left(30^{\circ} \mathrm{C}, 84\right.$ days) for different types of composted manures ${ }^{21,46}$ (see Inorganic $\mathrm{N}$ and ADSN determinations for predicting short-term N availability and Figs. S5 and S6 in Supplementary Information), Oyanagi et al. (ref. ${ }^{47}$ ) concluded that $\mathrm{N}$ available from an OF that contains $<250 \mathrm{mg} \mathrm{g}^{-1} \mathrm{ADOM}$ (95\% of the composted cattle manures used in the laboratory incubations ${ }^{46}$ belonged to this category) in the first application year can be estimated only by inorganic $\mathrm{N}$ in the OF. For an OF that contains $\geq 250 \mathrm{mg} \mathrm{g}^{-1} \mathrm{ADOM}$, 4-week (approximately 1 month) $\mathrm{N}$ availability can be assessed only by inorganic $\mathrm{N}$ in the OF, while 12 -week (approximately 3 months) $\mathrm{N}$ availability can be assessed by the equation of 0.50 ADSN -2.5 (ADSN is $\mathrm{N}$ in ADOM).

The kosi and fast compost contained soil, which made a determination of ADOM difficult. In this study, therefore, 12 -week $\mathrm{N}$ availability was assessed by the equation of $0.50 \mathrm{ADSN}-2.5$, while 4 -week $\mathrm{N}$ availability was assessed by inorganic $\mathrm{N}$ in the $\mathrm{OF} . \mathrm{N}$ mineralisation rates, i.e., the proportions of $\mathrm{N}$ available in total $\mathrm{N}$ of the $\mathrm{OF}$, were calculated in 4 weeks and 12 weeks of incubation to obtain 4 -week and 12 -week $\mathrm{N}$ mineralisation rates, respectively.

Multiple comparison tests (the Bonferroni correction) were conducted to detect differences in the mean values of inorganic $\mathrm{N}$ concentrations $\left(\mathrm{NH}_{4}{ }^{+}\right.$and $\left.\mathrm{NO}_{3}{ }^{-}\right)$, the ratio of $\mathrm{NH}_{4}{ }^{+}$to $\mathrm{NO}_{3}{ }^{-}\left(\mathrm{NH}_{4}{ }^{+}: \mathrm{NO}_{3}{ }^{-}\right)$, 4-week and 12-week $\mathrm{N}$ availability, and 4 -week and 12 -week $\mathrm{N}$ mineralisation rates between each pair of the OF samples (kosi, fast compost, and household wastes).

\section{Results}

Decomposition characteristics. The cluster analysis showed the organic material samples were classified into three groups (Fig. 2). The discrimination analysis showed the $1^{\text {st }}$ and $2^{\text {nd }}$ standardized canonical discriminant functions accounted for $58 \%$ and $42 \%$ of the total variance, respectively, being $99.8 \%$ of the total variance in total. Thus, the $1^{\text {st }}$ and $2^{\text {nd }}$ canonical scores were used to visualise how well the discriminant functions classified the data.

Both the groups 1 and 2 were mainly composed of the samples of crop residues. Both groups commonly had a higher OM (i.e., lower mineral) and the higher OM decomposable between 3 months and 3 years (i.e., higher cellulose or ADF-ADL; Table 3). The samples of maize and sorghum stovers and haricot beans shell and stalk were mainly of group 1 , while the samples of barley and tef straws were mainly of group 2. Group 2 was also characterised by the rich OM decomposable within 3 months (i.e., ADOM) including the OM decomposable within 14 days (i.e., readily decomposable $\mathrm{OM}$ ). Both the OM decomposable within 14 days and the OM decomposable within 3 months of the barley and tef straws was the highest among the organic materials, although no significant difference was observed between the organic materials.

Group 3 was mainly composed of the livestock dungs, which had the highest proportions of mineral (crude ash), and every indicator that represents OM degradability of group 3 was the lowest among the organic materials (except for the haricot beans shell and stalk; Table 3). The feed refusals spanned all the groups, probably because it was a mixture of livestock dungs and feeds, i.e., crop residues.

The kosi and fast compost had higher mineral contents, partly because it was likely to be affected by the soil contained (Table 3). Between the kosi and fast compost, no noticeable difference was observed in the indicators that represent OM degradability and the ratios between some indicators of the OM degradability. Of the 12 kosi and 10 fast compost samples, 8 and 4 samples contained substantially no OM fraction that is decomposable within 14 days, respectably, and the two OFs probably contained $<250 \mathrm{mg} \mathrm{g}^{-1} \mathrm{ADOM}$. The (OM decomposable 


\begin{tabular}{|c|c|c|c|c|c|c|c|c|c|c|c|c|c|}
\hline \multirow[b]{2}{*}{ Items } & \multirow[b]{2}{*}{$n$} & \multirow[b]{2}{*}{ Groups $^{\mathrm{a}}$} & \multicolumn{6}{|c|}{ Mineral and OM contents and indicators of OM degradability $\left(\mathrm{mg} \mathrm{g}^{-1}\right)^{b}$} & \multicolumn{5}{|c|}{ Ratios between some indicators of OM degradability ${ }^{c}$} \\
\hline & & & Mineral & OM & $\begin{array}{l}\text { (a) within } \\
14 \text { days }\end{array}$ & $\begin{array}{l}\text { (b) within } 3 \\
\text { months }\end{array}$ & $\begin{array}{l}\text { (c) } 3 \\
\text { mos.-3 yrs. }\end{array}$ & $\begin{array}{l}\text { (d) within } 3 \\
\text { years }\end{array}$ & (a) $/(\mathbf{c})$ & (a) $/(\mathbf{d})$ & (b)/(c) & (b) $/(\mathbf{d})$ & $(\mathbf{c}) /(\mathbf{d})$ \\
\hline Maize stover & 6 & 1 & $106 \pm 17^{\mathrm{a}}$ & $894 \pm 17^{\mathrm{a}}$ & $60 \pm 20^{n s}$ & $318 \pm 54^{n s}$ & $434 \pm 54^{\mathrm{a}}$ & $751 \pm 71^{\text {ac }}$ & $0.1 \pm 0.1^{\mathrm{a}}$ & $0.1 \pm 0.0^{\mathrm{a}}$ & $0.8 \pm 0.1^{\mathrm{ab}}$ & $0.4 \pm 0.0^{\mathrm{ab}}$ & $0.6 \pm 0.0^{\mathrm{ab}}$ \\
\hline Sorghum stover & 6 & 1,2 & $109 \pm 22^{a}$ & $891 \pm 22^{a}$ & $60 \pm 15^{n s}$ & $318 \pm 42^{n s}$ & $354 \pm 40^{\text {ac }}$ & $672 \pm 44^{\text {ab }}$ & $0.2 \pm 0.0^{\mathbf{b}}$ & $0.1 \pm 0.0^{\mathrm{a}}$ & $0.9 \pm 0.2^{\mathrm{ab}}$ & $0.5 \pm 0.0^{\mathrm{ab}}$ & $0.5 \pm 0.0^{\mathrm{ab}}$ \\
\hline Haricot beans & 6 & 1,2 & $131 \pm 26^{a}$ & $869 \pm 26^{a}$ & $45 \pm 51^{n s}$ & $243 \pm 182^{n s}$ & $505 \pm 157^{\mathbf{a b}}$ & $747 \pm 33^{\text {ac }}$ & $0.3 \pm 0.3^{b}$ & $0.1 \pm 0.1^{\mathrm{a}}$ & $0.6 \pm 0.6^{\mathrm{a}}$ & $0.3 \pm 0.2^{\mathrm{a}}$ & $0.7 \pm 0.2^{\mathrm{a}}$ \\
\hline Barley straw & 6 & 1,2 & $126 \pm 19^{\mathrm{a}}$ & $874 \pm 19^{a}$ & $91 \pm 50^{n s}$ & $403 \pm 137^{n s}$ & $315 \pm 101^{\text {ab }}$ & $719 \pm 47^{\text {acd }}$ & $0.3 \pm 0.4^{\mathrm{b}}$ & $0.1 \pm 0.1^{\mathrm{a}}$ & $1.6 \pm 1.5^{\mathrm{ab}}$ & $0.6 \pm 0.2^{\mathrm{ab}}$ & $0.4 \pm 0.2^{\mathrm{ab}}$ \\
\hline Tef straw & 6 & 1,2 & $96 \pm 14^{\mathrm{a}}$ & $904 \pm 14^{\mathrm{a}}$ & $106 \pm 55^{n s}$ & $445 \pm 150^{n s}$ & $345 \pm 153^{\text {ab }}$ & $790 \pm 48^{c}$ & $0.3 \pm 0.3^{\mathbf{b}}$ & $0.1 \pm 0.1^{\mathrm{a}}$ & $1.8 \pm 1.3^{\mathrm{ab}}$ & $0.6 \pm 0.2^{\mathrm{ab}}$ & $0.4 \pm 0.2^{\mathrm{ab}}$ \\
\hline Feed refusals & 6 & $1,2,3$ & $335 \pm 126^{\mathbf{a b}}$ & $665 \pm 126^{\mathrm{ab}}$ & $45 \pm 42^{n s}$ & $256 \pm 142^{n s}$ & $284 \pm 59^{b c}$ & $539 \pm 126^{\text {ac }}$ & $0.1 \pm 0.2^{\mathrm{ac}}$ & $0.1 \pm 0.1^{\text {ac }}$ & $1.0 \pm 0.6^{\mathrm{ab}}$ & $0.4 \pm 0.2^{\mathrm{ab}}$ & $0.6 \pm 0.2^{\mathrm{ab}}$ \\
\hline Cattle dung & 6 & $1,2,3$ & $352 \pm 154^{\mathrm{ab}}$ & $648 \pm 154^{\mathrm{ab}}$ & $49 \pm 42^{n s}$ & $291 \pm 156^{n s}$ & $271 \pm 111^{\text {ab }}$ & $535 \pm 179^{\mathrm{ac}}$ & $0.2 \pm 0.2^{\mathrm{ac}}$ & $0.1 \pm 0.1^{\mathrm{ac}}$ & $1.3 \pm 1.1^{\mathrm{ab}}$ & $0.5 \pm 0.3^{\mathrm{ab}}$ & $0.5 \pm 0.3^{\mathrm{ab}}$ \\
\hline Sheep/goat dung & 6 & 2,3 & $382 \pm 86^{\mathbf{b}}$ & $618 \pm 86^{b}$ & $56 \pm 49^{n s}$ & $295 \pm 152^{n s}$ & $180 \pm 53^{\mathrm{b}}$ & $475 \pm 128^{b}$ & $0.2 \pm 0.2^{\mathrm{ac}}$ & $0.2 \pm 0.2^{\mathrm{a}}$ & $1.9 \pm 1.4^{\mathrm{b}}$ & $0.6 \pm 0.2^{b}$ & $0.4 \pm 0.2^{\mathrm{b}}$ \\
\hline Donkey dung & 6 & 2,3 & $327 \pm 57^{\mathbf{b}}$ & $673 \pm 57^{b}$ & $39 \pm 32^{n s}$ & $259 \pm 88^{n s}$ & $286 \pm 50^{\mathbf{b c}}$ & $545 \pm 61^{\text {bd }}$ & $0.4 \pm 0.4^{\mathrm{a}}$ & $0.1 \pm 0.1^{\mathrm{a}}$ & $1.0 \pm 0.5^{\mathrm{ab}}$ & $0.5 \pm 0.1^{\mathrm{ab}}$ & $0.5 \pm 0.1^{\mathrm{ab}}$ \\
\hline Kosi & 12 & & $674 \pm 143$ & $326 \pm 143$ & $10 \pm 19$ & $125 \pm 94$ & $119 \pm 49$ & $247 \pm 130$ & $0.1 \pm 0.1^{\text {ac }}$ & $0.0 \pm 0.0^{\mathbf{b c}}$ & $1.0 \pm 0.5^{\mathrm{ab}}$ & $0.5 \pm 0.1^{\mathrm{ab}}$ & $0.5 \pm 0.1^{\mathrm{ab}}$ \\
\hline Fast compost & 10 & & $674 \pm 23$ & $326 \pm 23$ & $3 \pm 4$ & $139 \pm 44$ & $120 \pm 38$ & $259 \pm 44$ & $0.0 \pm 0.1^{c}$ & $0.0 \pm 0.0^{\mathbf{b}}$ & $1.2 \pm 0.7^{\mathrm{ab}}$ & $0.5 \pm 0.1^{\mathrm{ab}}$ & $0.5 \pm 0.1^{\mathrm{ab}}$ \\
\hline
\end{tabular}

Table 3. Decomposition characteristics of organic fertilisers and organic materials from the study area (mean \pm SD, dry matter). ${ }^{a}$ Cluster analysis and canonical discriminant analysis were conducted to get cluster numbers of each organic material sample. ${ }^{\mathrm{b}}$ Analysis of variance was conducted between each pair of the organic materials. Different superscript letters between the organic materials indicate statistically significant differences $(P<0.05)$. ns not significant. ${ }^{c}$ Kruskal-Wallis tests were applied between each pair of the organic fertilisers and organic materials. OM, organic matter; a) OM fraction that is decomposable within 14 days, i.e., readily decomposable OM; b) OM fraction that is decomposable within 3 months, i.e., ADOM (acid detergent soluble organic matter); c) OM fraction that is decomposable between 3 months and 3 years, i.e., ADF (acid detergent fibre)-ADL (acid detergent fibre lignin); d) OM fraction that is decomposable within 3 years, i,e., 1000-ADLash.

\begin{tabular}{|c|c|c|c|c|c|c|c|c|}
\hline \multirow[b]{2}{*}{ Organic fertilisers } & \multirow[b]{2}{*}{$n$} & \multirow[b]{2}{*}{$\mathrm{NH}_{4}^{+}\left(\mathrm{mg} \mathrm{g}^{-1}\right)$} & \multirow{2}{*}{$\begin{array}{l}\mathrm{NO}_{3}^{-}(\mathrm{mg} \\
\left.\mathrm{g}^{-1}\right)\end{array}$} & \multirow[b]{2}{*}{$\mathrm{NH}_{4}^{+}: \mathrm{NO}_{3}^{-}$} & \multicolumn{2}{|c|}{$\mathrm{N}$ availability $\left(\mathrm{mg} \mathrm{g}^{-1}\right)$} & \multicolumn{2}{|c|}{ Mineralisation rates (\%) } \\
\hline & & & & & 4-week & 12-week & 4-week & 12-week \\
\hline Kosi & 10 & $0.011 \pm 0.006^{\mathrm{a}}$ & $0.50 \pm 0.29^{\mathrm{a}}$ & $0.03 \pm 0.02^{\mathrm{a}}$ & $0.51 \pm 0.29^{\mathrm{a}}$ & $1.37 \pm 1.08^{\mathrm{a}}$ & $4.0 \pm 1.6^{\mathrm{a}}$ & $11.2 \pm 8.9^{\mathrm{a}}$ \\
\hline Fast compost & 10 & $0.007 \pm 0.001^{\mathrm{a}}$ & $0.23 \pm 0.07^{b}$ & $0.03 \pm 0.01^{\mathrm{a}}$ & $0.23 \pm 0.07^{b}$ & $0.23 \pm 0.07^{b}$ & $3.9 \pm 1.2^{\mathrm{a}}$ & $3.9 \pm 1.2^{\mathrm{a}}$ \\
\hline Household wastes & 10 & $0.085 \pm 0.055^{\mathrm{b}}$ & $0.04 \pm 0.07^{\mathrm{c}}$ & $7.58 \pm 6.57^{\mathrm{b}}$ & $0.13 \pm 0.06^{\mathrm{c}}$ & $2.73 \pm 0.94^{\mathrm{c}}$ & $2.3 \pm 1.7^{\mathrm{a}}$ & $54.0 \pm 25.8^{b}$ \\
\hline
\end{tabular}

Table 4. $\mathrm{NH}_{4}{ }^{+}$and $\mathrm{NO}_{3}{ }^{-}$concentrations, $\mathrm{NH}_{4}{ }^{+}: \mathrm{NO}_{3}{ }^{-}$ratios, 4-week and 12-week $\mathrm{N}$ availability, and 4-week and 12 -week $\mathrm{N}$ mineralisation rates for the kosi, fast compost, and household wastes (mean $\pm \mathrm{SD}$ ). Different superscript letters between the organic fertilisers indicate statistically significant differences $(P<0.05)$. $n s$ not significant.

within 14 days)/(OM decomposable between 3 months and 3 years) of the two OFs were significantly lower than that of the most crop residues. The (OM decomposable within 14 days)/(OM decomposable within 3 years) of the kosi was significantly lower than that of all the crop residues, sheep/goat dung, and donkey dung, and that of the fast compost was significantly lower than that of all the organic materials. These suggest that the OM fraction that was decomposable within 14 days was more rapidly decomposed than other fractions of OM degradability in the composting process of the two OFs.

Short-term $\mathrm{N}$ availability. The multiple comparison tests showed that $\mathrm{NH}_{4}{ }^{+}$in the kosi and fast compost were significantly lower than that in the household wastes (Table 4). $\mathrm{NO}_{3}{ }^{-}$in the three OFs significantly differed from one another, being higher in the order of the kosi, fast compost, and household wastes. Only the kosi satisfied all the stability/maturity indices, whereas $\mathrm{NO}_{3}{ }^{-}$in the fast compost was lower than the critical limit value of stable/mature compost. The household wastes did not satisfy the stability/maturity indices of either $\mathrm{NO}_{3}{ }^{-}$or $\mathrm{NH}_{4}{ }^{+}: \mathrm{NO}_{3}{ }^{-}$ratio, probably still being in the composting process.

Inorganic $\mathrm{N}$ and ADSN determinations predicted that 4-week $\mathrm{N}$ availability from kosi will be significantly higher than that from fast compost and household wastes (Table 4). Additionally, because higher amounts of organic $\mathrm{N}$ will be mineralised from kosi and household wastes during the subsequent 8 weeks than from fast compost, 12-week $\mathrm{N}$ availability will be higher in the order of household wastes, kosi, and fast compost. While approximately $50 \%$ of total $\mathrm{N}$ will be mineralised in 12 weeks after a household wastes application, 12-week $\mathrm{N}$ mineralisation rates will be approximately $11 \%$ and $4 \%$ for $k o s i$ and fast compost, respectively.

Until 28 days of incubation, some of the kosi samples showed net $\mathrm{N}$ immobilisation, whereas the fast compost samples showed no noticeable change in net $\mathrm{N}$ mineralised (Fig. 3). In 28 days of incubation, all the net $\mathrm{N}$ mineralised of the kosi and fast compost exceeded $0 \mathrm{mg} \mathrm{g}^{-1}$, and net $\mathrm{N}$ mineralised in 35 and 42 days of incubation for the kosi were on average 0.48 and $0.49 \mathrm{mg} \mathrm{g}^{-1}$, respectively, and those of the fast compost were 0.08 and $0.19 \mathrm{mg} \mathrm{g}^{-1}$. All the household wastes samples had shown a slight $\mathrm{N}$ immobilisation until 21 to 28 days of 

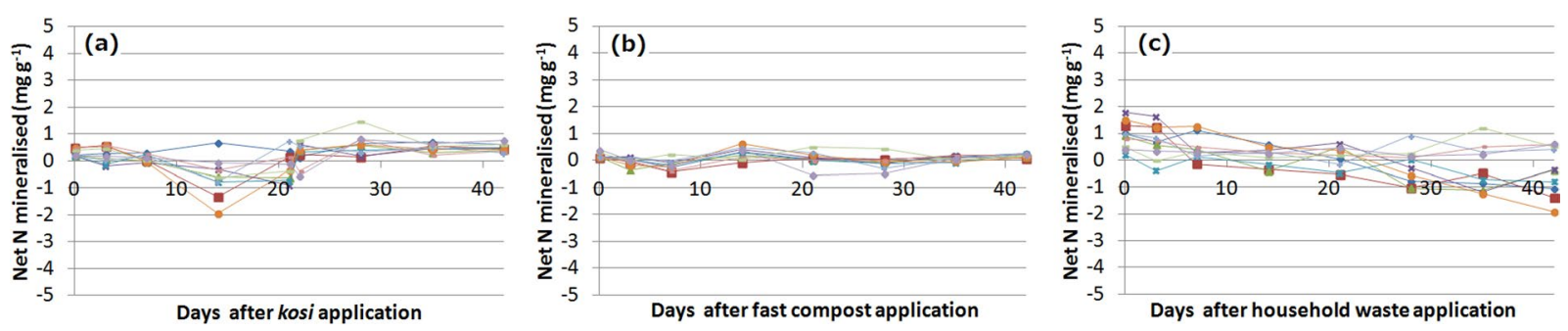

Figure 3. Net $\mathrm{N}$ mineralised during the 42-day incubation for the kosi (a), fast compost (b), and household wastes $(\mathbf{c})$ samples $(n=10$ for each). Different colour lines in each graph showed different samples.

incubation. Since then, they were divided into two groups: one N mineralisation of which prevailed (4 samples); another $\mathrm{N}$ immobilisation of which prevailed (6 samples).

\section{Discussion}

The mean net $\mathrm{N}$ mineralised from the kosi and fast compost in 42 days of incubation (Fig. 3) were almost equal to inorganic $\mathrm{N}$ in the kosi and fast compost, i.e., 4-week $\mathrm{N}$ availability (Table 4), respectively. This suggests that mineralised $\mathrm{N}$ that was derived from easily decomposable $\mathrm{OM}$ in approximately 1 month of incubation was nearly 0 , which was also supported by the $\mathrm{OM}$ fraction that is decomposable within 14 days (readily decomposable OM) contained in the kosi and fast compost (Table 3). The fast compost mean 12-week N availability was the same as the 4-week value (Table 4), indicating $\mathrm{N}$ mineralised from easily decomposable OM will continuously be negligible even approximately 3 months after a fast compost application. The amount of $\mathrm{N}$ available from manure includes the inorganic content of manure $\left(\mathrm{NH}_{4}{ }^{+}\right.$and $\left.\mathrm{NO}_{3}{ }^{-}\right)$plus the amount of organic $\mathrm{N}$ mineralised following application ${ }^{48}$. Both $\mathrm{NH}_{4}{ }^{+}$and $\mathrm{NO}_{3}{ }^{-}$in the fast compost were lower than those in the kosi, and the amount of organic $\mathrm{N}$ mineralised following the fast compost application will be 0 because the fast compost probably contained $<250 \mathrm{mgg} \mathrm{g}^{-1}$ ADOM.

This is in line with the prediction of short-term $\mathrm{N}$ availability from most of the cattle manures/composts shown by Tanahashi \& Oyanagi (ref. ${ }^{46}$; see Inorganic N and ADSN determinations for predicting short-term $\mathrm{N}$ availability and Fig. S5 in Supplementary Information). Markewich et al. (ref. ${ }^{17}$ ) conducted a litterbag experiment in Kenya with cattle manure samples with different feed qualities and storage methods and found that more of the refractory fibre-bound $\mathrm{N}$ remained in the low-quality manure, not mineralised during 4 months in soil. Eghball et al. (ref. ${ }^{48}$ ) found that organic $\mathrm{N}$ mineralized during the corn growing season (5 months) from composted cattle manure was about half $(11 \%)$ of that for noncomposted cattle feedlot manure $(21 \%)$. Eghball et al. $\left(\right.$ ref. $\left.^{48}\right)$ noted that lower $\mathrm{N}$ mineralisation from compost was because most of the easily convertible $\mathrm{C}$ and $\mathrm{N}$ compounds were lost during the composting process and the remaining $\mathrm{C}$ and $\mathrm{N}$ were in more stable forms. The rapid decomposition in the OM fraction that is decomposable within 14 days found in this study (Table 3) was in line with these findings. In contrast, additional $\mathrm{N}$ will be mineralised from the easily decomposable OM fraction of kosi during the period from 4-week to 12-week. This can be because a kosi pile includes immature kosi ADOM of which exceeds $250 \mathrm{mg} \mathrm{g}^{-1}$ (ADOM of haricot beans shell and stalk was a little less than $250 \mathrm{mg} \mathrm{g}^{-1}$; Table 3 ) as farmers pile up a fresh organic material on a mature kosi pile.

In the 84-day incubation tests, Tanahashi \& Oyanagi $\left(\right.$ ref. $^{46}$ ) showed that ADOM was also an appropriate indicator of $\mathrm{N}$ mineralisation patterns. $\mathrm{N}$ mineralisation patterns of the composted cattle manure that had $\geq 250 \mathrm{mg} \mathrm{g}^{-1} \mathrm{ADOM}$ ( $5 \%$ of the cattle manure samples) were characterised by an initial $\mathrm{N}$ immobilisation (4.7$5.3 \mathrm{mg} \mathrm{g}^{-1} \mathrm{~N}$ at maximum) occurred during the initial approximately 7 days of incubation, followed by $\mathrm{N}$ mineralisation (1.8-8.0 $\mathrm{mg} \mathrm{g}^{-1} \mathrm{~N}$ at maximum) during the remaining incubation period. In contrast, $\mathrm{N}$ mineralisation patterns of the composted cattle manure that had $<250 \mathrm{mg} \mathrm{g}^{-1} \mathrm{ADOM}$ ( $95 \%$ of the samples) were characterised by an unclear $\mathrm{N}$ mineralisation pattern and minor fluctuation $\left(0.5-1.0 \mathrm{mg} \mathrm{g}^{-1}\right.$ of maximum $\mathrm{N}$ immobilisation or $1.3-1.4 \mathrm{mg} \mathrm{g}^{-1}$ of maximum $\mathrm{N}$ mineralisation, if any) during the entire incubation period. However, some of the composts that had $100-175 \mathrm{mg} \mathrm{g}^{-1}$ ADOM showed $\mathrm{N}$ immobilisations began in approximately 56 days of incubation and lasted over the remaining incubation period. Those were 4 of the 5 composted cattle manure samples that had the highest C:N ratios (26.1-42.5) of the samples. Beauchamp $\left(\right.$ ref. $^{49}$ ) conducted maize yield trials with the application of IFs, chicken manure, liquid dairy cattle manure, and solid beef cattle manure for 3 years. The results showed that maize yield response to $100 \mathrm{~kg} \mathrm{~N} \mathrm{ha}^{-1}$ treatments was consistently in the general order of IFs $>$ chicken manure $>$ liquid dairy cattle manure $>$ solid beef cattle manure over 3 years; however, only in the $1^{\text {st }}$ year, maize yield with the solid manure treatment was lower than that with the control treatment (no input). This was because: (i) net $\mathrm{N}$ immobilisation occurred for the $1^{\text {st }}$ crop shortly after the solid manure (C:N ratio $=15.4)$ application; and (ii) lower soil $\mathrm{NO}_{3}{ }^{-}$with the solid manure treatment reflected the lower availability of $\mathrm{N}$. Occurrence of net $\mathrm{N}$ immobilisation shortly after an application of cattle manure that had a high C:N ratio $(\mathrm{C}: \mathrm{N}$ ratio $=15.9)$ was also reported ${ }^{50}$. The high $\mathrm{C}: \mathrm{N}$ ratio of cattle manure/compost is a feature commonly observed for kosi and those in Eastern and Southern Africa. The phenomena that net $\mathrm{N}$ immobilisation occurred initially for some of the kosi followed by a steady net $\mathrm{N}$ mineralisation to reach approximately the level of 4-week $\mathrm{N}$ availability during the remaining incubation period agree with the findings shown by Tanahashi \& Oyanagi (ref. ${ }^{46}$ ) and Beauchamp (ref. ${ }^{49}$ ).

Farmers in Eastern and Southern Africa carry OFs from their kraals and cattle sheds to a field and integrate it into the field by ploughing operations carried out after a couple of weeks ${ }^{51}$. Temesgen et al. (ref. ${ }^{52}$ ) studied the 
purposes of tillage in the two representative areas in the semi-arid northern Ethiopian Rift Valley. Almost all the farmers (98\%) in Melkawoba (relatively dry and sandy silt soil) and 50-52\% of the farmers in Wulinchity (relatively humid and silty clay soil) plough maize and tef fields at planting for integrating kosi and household wastes into the soils. Considering the net $\mathrm{N}$ immobilisation possibly occurs after kosi application, it can be recommended to integrate the kosi into field soil at the ploughing time that is carried out about one month before seeding. Integration into the soil before this possibly causes loss of available $\mathrm{N}$ derived from kosi, and integration into the soil after this possibly causes a lower rate of seedling emergence and yield reduction due to $\mathrm{N}$ immobilisation ${ }^{51}$.

Immature household wastes are a mixture of fresh organic materials itself because almost all of the OF organic materials can contain much of the readily decomposable OM (OM decomposable within 14 days; $\mathrm{ADOM} \geq 250 \mathrm{mg} \mathrm{g}^{-1}$; Table 3). Therefore, all the household wastes showed $\mathrm{N}$ immobilisation during 1 to 2 weeks of incubation (Fig. 3); $\mathrm{N}$ available to crops during this period will be quite unstable. The $\mathrm{NH}_{4}{ }^{+}: \mathrm{NO}_{3}{ }^{-}$ratio of the household wastes had a great standard deviation (Table 4), ranging from the minimum value of 0.02 to the maximum value of 18.27 . One household wastes sample $\mathrm{NH}_{4}{ }^{+}: \mathrm{NO}_{3}{ }^{-}$ratio of which was 0.02 had $0.007 \mathrm{mg} \mathrm{g}^{-1}$ of $\mathrm{NH}_{4}{ }^{+}$and $0.248 \mathrm{mg} \mathrm{g}^{-1}$ of $\mathrm{NO}_{3}^{-}$, being comparable to those levels of the kosi. This indicates the household wastes samples had different maturation stages ranging from a mixture of fresh organic materials to a mixture of organic materials that had left in farmers' backyard in a long period to pass the similar composting process to the kosi. Therefore, inputting a mixture of fresh organic materials directly to the field can pose more than one month of net $\mathrm{N}$ immobilisation after application. Farmers should stop a direct application of household wastes to the field; instead, household wastes should be piled up to make mature kosi and then applied to the field.

Lower short-term $\mathrm{N}$ availability is the other prevailing feature observed for both kosi and cattle manure/ compost in Eastern and Southern Africa. Inorganic $\mathrm{N}$ in the kosi was comparable to that in the 141 dairy manures from Central Kenya: mean 0.49, standard deviation 0.53, minimum 0.02, and maximum $1.69 \mathrm{mg} \mathrm{g}^{-116}$. Application of solid beef cattle manure at the rate of $100 \mathrm{~kg} \mathrm{~N} \mathrm{ha}^{-1}$ in Beauchamp (ref. ${ }^{49}$ ) was equivalent to $6.6 \mathrm{Mg}$ $\mathrm{ha}^{-1}$ of kosi application that contained the mean $1.52 \% \mathrm{~N}$ (Table 2). This is almost equal to the mean application rate of kosi to arada, $6.0 \mathrm{Mg} \mathrm{ha}^{-1} \mathrm{yr}^{-1}$, in the semi-arid northern Ethiopian Rift Valley ${ }^{25}$. Based on the 4-week and 12-week $\mathrm{N}$ availability from the kosi, 0.51 and $1.37 \mathrm{mg} \mathrm{g}^{-1}$ (Table 4), kosi application to an arada soil with the application rate of $6.0 \mathrm{Mg} \mathrm{ha}^{-1} \mathrm{yr}^{-1}$ can supply 3.0 and $8.2 \mathrm{~kg} \mathrm{~N} \mathrm{ha}^{-1} \mathrm{yr}^{-1}$ to the arada, respectively. These $\mathrm{N}$ availabilities are far below the recommended dose of fertiliser $\mathrm{N}$ use in Ethiopia, $64 \mathrm{~kg} \mathrm{~N} \mathrm{ha}^{-1} \mathrm{yr}^{-1}\left(100 \mathrm{~kg} \mathrm{ha}^{-1}\right.$ $\mathrm{Di}$-Ammonium Phosphate and $100 \mathrm{~kg} \mathrm{ha}^{-1}$ Urea). Given these, $k o s i$ and fast compost cannot be expected to contribute much to crop yield gains in the first application year.

Mukai (ref. ${ }^{25}$ ) conducted a maize yield trial in the semi-arid northern Ethiopian Rift Valley and confirmed that: (i) maize yield up to $\sim 5.0 \mathrm{Mg} \mathrm{ha}^{-1}$ can be linearly best explained solely by the soil available $\mathrm{N}$ concentration; and (ii) continuous application of kosi at the rates of $84 \mathrm{~kg} \mathrm{~N} \mathrm{ha}^{-1}$ (almost equivalent to $5.5 \mathrm{Mg} \mathrm{ha}^{-1} \mathrm{yr}^{-1}$ application) and $164 \mathrm{~kg} \mathrm{~N} \mathrm{ha}^{-1}$ (similarly, $10.8 \mathrm{Mg} \mathrm{ha}^{-1} \mathrm{yr}^{-1}$ ) for over ten years increased soil available $\mathrm{N}$ concentrations to the $3.0 \mathrm{Mg} \mathrm{ha}^{-1}$ and $4.0 \mathrm{Mg} \mathrm{ha}^{-1}$ yield levels of maize, respectively. In the field where kosi has been applied for over 20 years, significant improvements in soil chemical properties in general and part of soil physical properties (decrease in soil compaction and bulk density and increase in porosity) were observed ${ }^{53}$. Thus, cattle manure/ compost in Eastern and Southern Africa including kosi should not be considered to be quick-acting fertilisers; instead, it can be considered to be OFs that contribute to soil cultivation by their medium- or long-term application and to gain crop yields by the increase in total $\mathrm{C}$ and $\mathrm{N}$ in the field soil ${ }^{17,54}$.

Simple determination methods for $\mathrm{N}$ components by using RQFlex and the acid detergent fibre analysis methods used in this study can be implemented in agricultural experiment stations that equip a fume hood. These are quick, cost-saving, and yet accurate on-site quality assessment methods for OFs.

\section{Conclusions}

The kosi organic materials have diversified decomposition characteristics and yet commonly contain much of the $\mathrm{ADOM}$ that represents the OM decomposable within 3 months. In the composting process of the kosi and fast compost, the readily decomposable OM fraction was more rapidly lost. The kosi and fast compost samples had higher C:N ratios and low inorganic $\mathrm{N}$ contents, which are typical characteristics to cattle manure/compost in Eastern and Southern Africa. These factors can work together, and some of the kosi showed initial net $\mathrm{N}$ immobilisation, which was followed by net $\mathrm{N}$ mineralisation of all the kosi samples and then to the level of 4-week $\mathrm{N}$ availability. Kosi should be applied to the field one month before seeding.

Many of the household wastes samples did not meet the OF stability/maturity indices, being still in the composting process. Net $\mathrm{N}$ immobilisation prevailed for more than half of the household wastes samples for more than one month period. Household wastes should not be applied directly to the field; instead, it should be added to a kosi pile and used after being mature kosi.

In a kosi application year, $\mathrm{N}$ availability from the kosi is limited, and kosi shows low substitutability for IFs. The present local practices of continuous kosi application in the mid- to long-term, are best suited.

\section{Data availability}

All data analysed are included in this article (and its Supplementary Information file).

Received: 26 May 2019; Accepted: 18 October 2019;

Published online: 05 November 2019

\section{References}

1. Dixon, J., Gulliver, A. \& Gibbon, D. Sub-Saharan Africa in Farming Systems and Poverty: Improving Farmers' Livelihoods in a Changing World (FAO, 2001).

2. Yimer, F. \& Abdelkadir, A. Soil property changes following conversion of acacia woodland into grazing and farmlands in the Rift Valley area of Ethiopia. Land Degradation \& Development 22, 425-431 (2010). 
3. Morris, M., Kelly, V. A., Kopicki, R. J. \& Byerlee, D. Fertiliser Use in African Agriculture. Lessons Learned and Good Practice Guidelines (World Bank, 2007).

4. Bationo, A. et al. Overview of long term experiments in Africa in Lessons Learned from Long-Term Soil Fertility Management Experiments in Africa (ed. Bationo, A. et al.) 1-26 (Springer, 2012).

5. Chivenge, P., Vanlauwe, B. \& Six, J. Does the combined application of organic and mineral nutrient sources influence maize productivity? A meta-analysis. Plant and Soil 342, 1-30 (2011).

6. Kimani, S. K. \& Lekasi, J. K. Managing manures throughout their production cycle enhances their usefulness as fertilizers: a review in Managing Nutrient Cycles to Sustain Soil Fertility in Sub-Saharan Africa (ed. Batiano, A.) 187-198 (Academy of Science Publishers, 2004).

7. Woomer, P. L., Karanja, N. K. \& Okalebo, J. R. Opportunities for improving integrated nutrient management by smallhold farmers in the Central Highlands of Kenya. African Crop Science Journal 7(4), 441-454 (1999).

8. Gachengo, C. N., Vanlauwe, B., Palm, C. A. \& Cadisch, G. Chemical characterisation of a standard set of organic materials in Modelling Nutrient Management in Tropical Cropping Systems (eds Delve, R. J. \& Probert, M. E.) 48-53 (Australian Centre for International Agricultural Research, 2004a).

9. Okalebo, J. R. et al. Use of organic and inorganic resources to increase maize yields in some Kenyan infertile soils: a five-year experience in Managing Nutrient Cycles to Sustain Soil Fertility in Sub-Saharan Africa (ed. Batiano, A.) 359-372 (Academy Science Publishers, 2004).

10. Gómez, R. B., Vázquez-Lima, F. \& Sánchez-Ferrer, A. The use of respiration indices in the composting process: A review. Waste Manage. Res. 24, 37-47 (2006).

11. Wu, L. L., Ma, Q. \& Martinez, G. A. Comparison of methods for evaluating stability and maturity of biosolids compost. Journal of Environmental Quality 29(2), 424-429(2000).

12. Palm, C. A. \& Rowland, A. P. Chemical characterization of plant quality for decomposition in Driven by Nature: Plant Litter Quality and Decomposition (eds Cadisch, G. \& Giller, K. E.) 379-392 (CAB International, 1997).

13. Lupwayi, N. Z., Girma, M. \& Haque, I. Plant nutrient contents of cattle manures from small-scale farms and experimental stations in the Ethiopian highlands. Agriculture, Ecosystems and Environment 78, 57-63 (2000).

14. Onduru, D. D. et al. Manure and soil fertility management in sub-humid and semi-arid farming systems of sub-Saharan Africa: experiences from Kenya. International Journal of Agricultural Research 3(3), 166-187 (2008).

15. Tittonell, P., Rufino, M. C., Janssen, B. H. \& Giller, K. E. Carbon and nutrient losses during manure storage under traditional and improved practices in smallholder crop-livestock systems-Evidence from Kenya. Plant and Soil 328, 253-269 (2009).

16. Lekasi, J. K., Tanner, J. C., Kimani, S. K. \& Harris, P. J. C. Cattle manure quality in Maragua District, Central Kenya: effect of management practices and development of simple methods of assessment. Agriculture, Ecosystems and Environment 94, 289-298 (2003).

17. Markewich, H. A. et al. Effects of storage methods on chemical composition of manure and manure decomposition in soil in smallscale Kenyan systems. Agriculture Ecosystems \& Environment 139, 134-141 (2010).

18. Giller, K. E. Translating science into action for agricultural development in the tropics: an example from decomposition studies. Applied Soil Ecology 14, 1-3 (2000).

19. Palm, C. A., Gachengo, C. N., Delve, R. J., Cadisch, G. \& Giller, K. E. Organic inputs for soil fertility management in tropical agroecosystems: application of an organic resource database. Agriculture, Ecosystems and Environment 83, 27-42 (2001).

20. Gachengo, C. N., Vanlauwe, B. \& Palm, C. A. Mineralisation patterns of selected organic materials in Modelling Nutrient Management in Tropical Cropping Systems (eds Delve, R. J. \& Probert, M. E.) 54-61 (Australian Centre for International Agricultural Research, 2004b).

21. Barrio, E. The in vitro dry matter digestibility (IVDMD) method in Modelling Nutrient Management in Tropical Cropping Systems (eds Delve, R. J. \& Probert, M. E.) 62-64 (Australian Centre for International Agricultural Research, 2004).

22. Shepherd, K. D. Predicting decomposition rates of organic resources using near infrared spectroscopy in Modelling Nutrient Management in Tropical Cropping Systems (eds Delve, R. J. \& Probert, M. E.) 65-68 (Australian Centre for International Agricultural Research, 2004).

23. Vanlauwe, B. Analysis of organic resource quality for parameterization of simulation models in Modelling Nutrient Management in Tropical Cropping Systems (eds Delve, R. J. \& Probert, M. E.) 69-74 (Australian Centre for International Agricultural Research, 2004).

24. Oyanagi, W. \& Tanahashi, T. Estimation of nitrogen fertilizer effect on cattle compost and swine compost by acid detergent digestible nitrogen. Japanese Journal of Soil Science and Plant Nutrition 81(2), 144-147 (2010) (in Japanese).

25. Mukai, S. Historical role of manure application and its influence on soil nutrients and maize productivity in the semi-arid Ethiopian Rift Valley. Nutrient Cycling in Agroecosystems 111(2-3), 127-139 (2018).

26. Abegaz, A., Keulen, H., Haile, M. \& Oosting, S. J. Nutrient dynamics on smallholder farms in Teghane, northern Highlands of Ethiopia in Advances in Integrated Soil Fertility Management in Sub-Saharan Africa: Challenges and Opportunities (eds Bationo, A, Waswa, B., Kihara, J. \& Kimetu. J.) 365-378 (Springer, 2007).

27. Chefetz, B., Hatcher, P. G., Hadr, Y. \& Chen, Y. Chemical and biological characterization of organic matter during composting of municipal solid waste. J. Environ. Qual. 25, 776-785 (1996).

28. Ministry of Agriculture and Rural Development (MoARD), Ethiopia Community Based Participatory Watershed Development: A Guideline (MoARD, 2005)

29. Tulema, B., Aune, J. B. \& Breland, T. A. Availability of organic nutrient sources and their effects on yield and nutrient recovery of Tef [Eragrostis tef (Zucc.) Trotter] and on soil properties. J. Plant Nutr. Soil Sci. 170, 543-550 (2007).

30. Shepherd, K. D., Palm, C. A., Gachengo, C. N. \& Vanlauwe, B. Rapid characterization of organic resource quality for soil and livestock management in tropical agroecosystems using near-infrared spectroscopy. Agron. J. 95, 1314-1322 (2003).

31. Fujiwara, T., Murakami, K., Tanahashi, T. \& Oyanagi, W. Applicability of near infrared spectroscopy as an alternative to acid detergent analysis for cattle and swine manure compost. Soil Science and Plant Nutrition 55, 170-178 (2009).

32. Oyanagi, W., Ando, Y. \& Tanahashi, T. Decomposition property of organic matters in soil and its indicators. Japanese Journal of Soil Science and Plant Nutrition 78(4), 407-410 (in Japanese) (2007).

33. Nishida, M. Nitrogen dynamics of organic materials applied to paddy fields: direct evaluation using organic materials labelled with nitrogen-15. Japan Agricultural Research Quarterly 45(1), 31-38, https://www.jstage.jst.go.jp/article/jarq/45/1/45_1_31/_pdf (2011).

34. Ando, Y., Oyanagi, W. \& Moriyama, N. A simple method for the determination of nutrients content in organic matter using the small reflection photometer. Japanese Society of Soil Science and Plant Nutrition 75(5), 605-608 (in Japanese) (2004).

35. Oyanagi, W., Muramatsu, K. \& Kobashi, Y. Recommendation of effective utilization of biomass and composts based on organic matter decomposition property. Bulletin of the Niigata Animal Husbandry Experiment Station 17, 9-14 (in Japanese) (2011).

36. Oyanagi, W., Tanahashi, T., Muramatsu, K. \& Kobashi, Y. Utility of acid detergent soluble organism as index of decomposing organic materials easily. Japanese Journal of Soil Science and Plant Nutrition 81(4), 383-386 (in Japanese) (2010).

37. Van Soest, P. J. Use of detergents in the analysis of fibrous feeds. II. A rapid method for the determination of fibre and lignin. Association of Official Analytical Chemists 46, 829-835 (1963).

38. Rowland, A. P. \& Roberts, J. D. Lignin and cellulose fractionation in decomposition studies using acid-detergent fibre methods. Communications in Soil Sciences and Plant Analysis 25, 269-277 (1994). 
39. Van Kessel, J. A. \& Reeves, J. B. On-farm quick tests for estimating nitrogen in dairy manure. Journal of Dairy Science 83, 1837-1844 (2000).

40. Matsumoto, T. Studies on the fertility management of timothy sward based on use of dairy cattle manures evaluated as available nutrients. Bulletin of Hokkaido Reserch Organization Agricultural Experiment Stations 121, 1-61 (in Japanese) (2008)

41. Tanahashi, T., Yano, H., Itou, H. \& Oyanagi, W. Magnesium ammonium phosphate in cattle and swine manure composts and an extraction method for its evaluation. Japanese Society of Soil Science and Plant Nutrition 81(4), 329-335 (in Japanese with English summary) (2010).

42. Zucconi, F. \& de Bertoldi, M. Compost specification for the production and characterization of compost from municipal solid waste in Compost: Production, Quality and Use (eds de Bertoldi, M., Ferranti, M. P., Hermite, P. L. \& Zucconi, F.) 30-50 (Elsevier Applied Science Publishers, 1987).

43. Forster, J. C., Zech, W. \& Wiirdinger, E. Comparison of chemical and microbiological methods for the characterization of the maturity of composts from contrasting sources. Biol. Fertil. Soils 16, 93-99 (1993).

44. Brewer, L. J. \& Sullivan, D. M. Maturity and stability evaluation of composted yard trimmings. Compost Sci. Util. 11(2), 96-112 (2003).

45. Kyvsgaard, P., Sørensen, P., Møller, E. \& Magid, J. Nitrogen mineralization from sheep faeces can be predicted from the apparent digestability of the feed. Nutrient Cycling in Agroecosystems 57, 207-214 (2000).

46. Tanahashi, T. \& Oyanagi, W. Estimation of nitrogen fertilizer efficiency of cattle and swine manure composts based on aciddetergent-soluble organic matter and inorganic nitrogen. Japanese Society of Soil Science and Plant Nutrition 81(4), 336-342 (in Japanese with English summary) (2010).

47. Oyanagi, W., Tanahashi, T., Murakami, K., Ishioka, I. \& Kato, N. Estimation of plant available nitrogen supply from livestock manure and compost in the first application year. Abstract of the annual meetings. Japanese Journal of Soil Science and Plant Nutrition 55, 147 (in Japanese) (2009).

48. Eghball, B., Wienhold, B. J., Gilley, J. E. \& Eigenberg, R. A. Mineralization of manure nutrients. Journal of Water and Soil Conservation 57(6), 470-473 (2002).

49. Beauchamp, E. G. Availability of nitrogen from three manures to corn in the field. Can. J. Soil Sci. 66, 713-720 (1986).

50. Castellanos, J. Z. \& Pratt, P. F. Mineralization of manure nitrogen-correlation with laboratory indexes. Soil Sci. Soc. Am. J. 45, 354-357 (1981)

51. Mkhabela, T. S. \& Materechera, S. A. Influence of kraal manure application time on emergence, growth and grain yield of maize grown in two soils with contrasting textures. Journal of Food, Agriculture \& Environment 11, 422-427 (2013).

52. Temesgen, M., Rockstrom, J., Savenije, H. H. G., Hoogmoed, W. B. \& Alemu, D. Determinants of tillage frequency among smallholder farmers in two semi-arid areas in Ethiopia. Physics and Chemistry of the Earth 33, 183-191 (2008).

53. Mukai, S. Assessment of long-term soil dynamics at manured fields with field measurement and interviews: a case study in the semiarid Ethiopian Rift Valley. Agroecology and Sustainable Food Systems 43(3), 261-273 (2019).

54. Edmeades, D. C. The long-term effects of manures and fertilisers on soil productivity and quality: a review. Nutrient Cycling in Agroecosystems 66, 165-180 (2003).

55. Mkhabela, T. S. \& Materechera, S. A. Factors influencing the utilization of cattle and chicken manure for soil fertility management by emergent farmers in the moist Midlands of KwaZulu-Natal Province, South Africa. Nutrient Cycling in Agroecosystems 65, 151-162 (2003).

56. Lekasi, J. K., Tanner, J. C., Kimani, S. K. \& Harris, P. J. C. Manure Management in the Kenya Highlands: Practices and Potential (The Henry Doubleday Research Association, 2001).

57. Jackson, H. L. \& Mtengeti, E. J. Assessment of animal manure production, management and utilization in Southern Highlands of Tanzania. Livestock Research for Rural Development 17(110) (2005).

58. Peters, J. et al. Recommended Methods of Manure Analysis. (University of Wisconsin-Extension, 2003).

59. National Soil Research Center (NSRC) and Ethiopian Agricultural Research Organization (EARO) Procedures for Soil and Plant Analysis (NSRC \& EARO, 2000)

60. Jankauskas, B., Jankauskiene, G., Slepetiene, A., Fullen, M. A. \& Booth, C. A. International comparison of analytical methods of determining the soil organic matter content of Lithuanian Eutric Albeluvisols. Communications in Soil Science and Plant Analysis 37(5-6), 707-720 (2006).

\section{Acknowledgements}

The authors would like to express profound gratitude to the Merko Odalega, Dongore Tiyo, and Koka Gifawasen villagers. Part of this study was financially supported by the Ministry of Agriculture, Forestry and Fisheries, Japan. Suggestions made by the reviewer and editor helped improve the structure of the paper.

\section{Author contributions}

Shiro Mukai wrote the main manuscript text and figures. Wataru Oyanagi made helpful suggestions on how to improve the manuscript. All authors reviewed the manuscript.

\section{Competing interests}

The authors declare no competing interests.

\section{Additional information}

Supplementary information is available for this paper at https://doi.org/10.1038/s41598-019-52497-8.

Correspondence and requests for materials should be addressed to S.M.

Reprints and permissions information is available at www.nature.com/reprints.

Publisher's note Springer Nature remains neutral with regard to jurisdictional claims in published maps and institutional affiliations. 
(c) (i) Open Access This article is licensed under a Creative Commons Attribution 4.0 International License, which permits use, sharing, adaptation, distribution and reproduction in any medium or format, as long as you give appropriate credit to the original author(s) and the source, provide a link to the Creative Commons license, and indicate if changes were made. The images or other third party material in this article are included in the article's Creative Commons license, unless indicated otherwise in a credit line to the material. If material is not included in the article's Creative Commons license and your intended use is not permitted by statutory regulation or exceeds the permitted use, you will need to obtain permission directly from the copyright holder. To view a copy of this license, visit http://creativecommons.org/licenses/by/4.0/.

(C) The Author(s) 2019 